\title{
Chronic Heart Failure and the Immune System
}

\section{Daniela Mari, * Federica Di Berardino, and Massimo Cugno}

\author{
Department of Internal Medicine, University of Milan, Maggiore Hospital \\ IRCCS, Via Pace 15, 20122 Milan, Italy
}

\begin{abstract}
Several lines of evidence support a role of immune mechanisms in the pathogenesis of chronic heart failure (CHF). Proinflammatory cytokines (interleukin-1, -2, -6, and tumor necrosis factor) and chemokines are involved in cardiac depression and in the progression of heart failure. Other components believed to be relevant to the pathogenesis of $\mathrm{CHF}$ are adhesion molecules, autoantibodies, nitric oxide (NO), and endothelin- 1 . The origin of the immune activation in patients with CHF is still unknown, however two hypotheses have been proposed on the basis of experimental and clinical data. One suggests that the bowel wall edema leads to bacterial translocation with subsequent endotoxin release and immune activation. The second suggests that the heart in CHF is the main source of cytokines, as is shown by the fact that $\mathrm{TNF} \alpha$ is produced by the failing myocardium but not by a normal one. No single source of cytokine production (gut or heart) seems sufficient to fully explain the multiple organ involvement and the systemic inflammation of $\mathrm{CHF}$, which is probably related to systemic hypoxia, a potent stimulus for activation of the immune system and for cytokine production. The effort to define the immune system's role has opened new perspectives of therapeutic strategies, such as anti-cytokine drugs, to treat CHF.
\end{abstract}

Index Entries: Heart failure; cytokines; autoantibodies; adhesion molecules; complement; endothelin.

\footnotetext{
*Author to whom all correspondence and reprint requests should be addressed. E-mail: daniela.mari@unimi.it
} 


\section{Introduction}

Chronic heart failure (CHF) is a syndrome characterized by fatigue, shortness of breath, congestion, and cachexia, symptoms related to the inadequate perfusion of tissue during exertion and often to the retention of fluid. Its primary cause is an impairment of the heart's ability to fill or empty the left ventricle properly (1). Vascular and neuroendocrine mechanisms are important contributors to the abnormalities in regional blood flow, renal sodium retention, and pulmonary congestion that lead to symptoms. Activation of the reninangiotensin system and the sympathetic nervous system contribute to the structural changes in the heart and peripheral vasculature that lead to the progressive remodeling of the left ventricle in CHF (2-4).

After the earliest report of high serum levels of tumor necrosis factor- $\alpha$ (TNF- $\alpha$ ) in CHF patients (5), several studies have shown a role of immune mechanisms in the pathogenesis of CHF (6). In particular, proinflammatory cytokines (interleukin-1 [IL-1], IL-2, IL-6, and TNF) are involved in cardiac depression and in the progression of the heart failure. Chemokines, which are cytokines with chemotactive activity such as IL-8, are also involved in cardiac dysfunction and considered markers of tissue damage (7). Other components believed to be relevant to the pathogenesis of CHF are adhesion molecules, autoantibodies, nitric oxide (NO), and endothelin-1 (8). The effort to define the immune system's role was stimulated by the possibility of using new therapeutic strategies, such as anti-cytokine drugs, to treat CHF.

\section{Tumor Necrosis Factor}

The important role of tumor necrosis factor (TNF) in heart failure has first postulated by Levine et al. in 1990 (5), who found high circulating levels of TNF- $\alpha$ in CHF. Patients with the highest values were more cachectic and had more advanced heart failure, as evidenced by their high plasma renin activity and low serum sodium concentrations. Subsequent investigators confirmed the high plasma levels of TNF in $\mathrm{CHF}$ and reported a relation between circulating levels of TNF and clinical features of the disease (9-14). A study on myocardial biopsies found TNF- $\alpha$ was high in the myocardium of CHF patients, especially in end stages, and plasma levels of TNF- $\alpha$ correlated with mRNA expression in the myocardium (15). Thus plasma levels of TNF- $\alpha$ may also serve as a marker of myocardial cytokine activation. Measures that improved heart failure were accompanied by a decrease in circulating TNF (16).

Experimental studies in animals showed that TNF and the other proinflammatory cytokines had a direct negative inotropic effect (17), 
probably through a myocardial nitric oxide synthase (NOS) (18). The high TNF concentrations affect NO-mediated vasodilatation in $\mathrm{CHF}$ (12). These high TNF- $\alpha$ levels were also associated with increased pulmunary vascular permeability, left ventricular remodeling, and the development of dilated cardiomyopathy (19-21).

TNF- $\alpha$ can induce wasting and apoptosis in skeletal muscle, as shown in animals $(22,23)$. TNF- $\alpha$ levels are very high in cachectic CHF patients and have been found to be the strongest predictors of weight loss (24). Thus TNF- $\alpha$ is potentially responsible for many of the clinical features of $\mathrm{CHF}$.

TNF- $\alpha$ exerts its cellular actions by two specific receptors, TNFR1 and TNFR2, which are present in all cells except red blood cells (25). In 1995, Ferrari et al. reported that it was essential to measure these receptors to assess the activation of TNF in CHF. They found that the soluble forms of both TNFR1 and TNFR2 were increased and that they might inhibit the cytotoxicity of TNF- $\alpha$ because there was a discrepancy between the antigenic and biological activity of TNF- $\alpha$ (26). Although the roles of these receptors are still not clear, it has been evidenced that both molecules have prognostic value. Soluble TNFR2 levels are independently correlated with poor short-term prognosis (26) and are a good predictor of mortality (27). Soluble TNFR1 was found to be the strongest and most accurate prognosticator, independent of established markers of CHF severity (28).

\section{Interleukin-1}

The effect of IL-1 on cardiac function is controversial. It acts as a growth factor for fibroblasts, lymphocytes, and smooth muscle cells $(29,30)$, but it also exerts a potent anti-proliferative effect on cardiac fibroblasts although it induces cardiac myocyte hypertrophy (31). IL-1ß increases in the failing heart (32) and depresses myocardial contractility by stimulating NOS (33). Moreover, it inhibits cardiac myocyte beta-adrenergic responsiveness (34).

\section{Interleukin-6}

IL-6 plasma levels are high in $\mathrm{CHF}(14,35,36)$ and have been associated with a worse New York Heart Association (NYHA) functional class and related to the severity of disease and hospital mortality $(37,38)$. The mechanism by which IL-6 exerts its deleterious effects is not known, but there is initial evidence that it is involved in the development of ventricular hypertrophy by an interaction with a receptor known as glycoprotein 130 (gp130), expressed on the cardiac myocyte (39). IL-6 levels are high in patients with left ventricular dysfunction even in the absence of the clinical syndrome of CHF (40) and are con- 
sidered a prognostic marker associated with poor prognosis in $\mathrm{CHF}$ $(41,42)$. Although in the left ventricular dysfunction trial (SOLVD), no relation was found between IL-6 plasma levels and survival (14), the VEST trial on 1200 patients found that IL-6, like TNF and TNF receptors, were an independent predictors of mortality in patients with CHF (27).

\section{Interleukin-2}

IL-2 has negative inotropic effects in vitro (17) and intravenous high-dose IL-2 causes important cardiovascular side effects such as hypotension, fluid retention, arrhythmias, and myocardial ischemia (43). Although there are some divergent reports (44), IL-2 is usually high in CHF patients, confirming activation of cellular components of the immune system (12). IL-2 exerts its cellular function through its receptor IL-2R, induced by T-cell activation. A study published in 1993 (45), described increased concentrations of soluble IL-2 receptors (indicative of T-lymphocyte activation), soluble CD8 and neopterin (a product of activated macrophages), and detectable interferon- $\gamma$ (IFN- $\gamma$ ) in some patients with $\mathrm{CHF}$, concluding there was a cellular immune activation. IL-2 and IL-2R are both correlated with the severity of CHF $(35,46)$. The increase of soluble IL-2 receptors (sIL-2R) levels in CHF has been confirmed, with an increase of the soluble antiapoptotic molecule sFas (47). The high level of sIL2-R was positively correlated with the increase of sFas, suggesting a relationship between programmed myocyte cell death and activation of the immune system in this situation (47).

\section{Chemokines}

Activation and migration of leukocytes to areas of myocardial inflammation appear to be important in CHF (48). Chemokines are potent chemoattractants of monocytes and lymphocytes and can influence other functions of these cells, such as generation of cytokines and reactive oxygen species (ROS). Their importance in cardiac damage and cardiac muscle dysfunction is illustrated by some experimental findings (49-51). In 1998, Aukrust et al. reported for the first time in patients with CHF high levels of chemokines, particularly the macrophage chemoattractant protein-1 (MCP-1), macrophage inflammatory protein1 alpha (MIP-1 $\alpha$ ), and RANTES (Regulated on Activation Normally T-cell Expressed and Secreted).

In patients with CHF, the increases of MCP-1, MIP- $1 \alpha$, and RANTES seemed to be caused by higher release from monocytes and also from CD3-leukocytes and platelets (48). Analysis of three other chemokines, IL-8, growth-regulated oncogene alpha (GRO $\alpha$ ) and epi- 
thelial neutrophil activating peptide (ENA)-78, gave similar data in patients with CHF. IL- 8 and GRO $\alpha$ showed a gradual increase parallel to increasing NYHA class, in addition there was an inverse correlation between IL-8 and left ventricular ejection fraction and cardiac index (7). Thus chemokines seem to be important mediators in the persistent immune activation observed in CHF patients, by activating circulating neutrophils, T-cells, and monocytes and possibly by recruiting these cells into the failing myocardium.

\section{Autoantibodies}

Antibodies against myocardial proteins were detected in $46 \%$ of patients with dilated cardiomyopathy suggesting an autoimmune involvement in dilated cardiomyopathy (52). The fact that organspecific cardiac antibodies were observed also in healthy asymptomatic relatives of patients with dilated cardiomyopathy (53), provides evidence that they are not induced by myocardial injury and their measurement might be useful for familial screening (54).

Autoantibodies against human beta-adrenergic receptors have also been observed in in approx $25 \%$ of patients with cardiomyopathy and were associated with a significantly poorer left ventricular function $(55,56)$. These autoantibodies can have widely differing allosteric effects ranging from inhibitory to agonist-promoting activities; however, they are associated with severe cardiac dysfunction (57). The elimination of autoantibodies directed against beta-adrenergic receptors using immunoadsorbtion techniques, and eventual IgG substitution seemed to improve symptoms and cardiac performance in dilated cardiomyopathy (58-60).

\section{Adhesion Molecules}

Adhesion molecules mediate the interaction between endothelial cells and circulating leukocytes $(61,62)$. There are three general classes of adhesion molecules on leukocytes and endothelium: integrins (CD11a,b,c/CD18), selectins (platelet selectin [P-selectin], and endothelial selectin [E-selectin]), and members of the immunoglobulin superfamily of cell surface proteins (intercellular adhesion molecule-1 [ICAM-1] and vascular cell adhesion molecule-1 [VCAM-1]) (63). In response to cytokines such as TNF- $\alpha$, endothelial cells sequentially express different adhesion molecules that preferentially bind different leukocytes, inducing them to infiltrate tissues $(64,65)$. In $\mathrm{CHF}$ the expression of adhesion molecules by TNF- $\alpha$ is upregulated, and this may cause the infiltration of mononuclear cells into the myocardium $(61,66)$. Upregulation of adhesion molecules such as ICAM-1 and 
integrin CD11a/CD18, and the presence of macrophages expressing TNF- $\alpha$ has in fact been described in the myocardium of patients with CHF (67). High plasma levels of soluble ICAM-1, which reflects enhanced expression of the adhesion molecule on the cell surface, have been observed in patients with CHF and correlated with the severity as indicated by NYHA class, suggesting a possible prognostic role (68). Other soluble adhesion molecules (VCAM-1, P-selectin, and E-selectin) are also increased in CHF (69).

\section{Complement System}

Activation of the complement system may cause ventricular damage or dysfunction through several mechanisms, including vasoconstriction, ischemia, and apoptosis $(70,71)$. Complement activation can also contribute to cardiac injury through its effect on cytokine production (72). Although the mechanisms of complement activation in CHF are not known, significant activation of the complement system has been seen in patients with symptomatic CHF and an association has been observed between high levels of circulating terminal complement complex (C5b-9) and near-term adverse events (73).

\section{Endothelins}

Endothelins (ET) are potent vasoconstrictor peptides released by endothelial cells, expressed in four isoforms, ET-1, ET-2, ET-3, and ET-4. Their production is stimulated by cytokines (74-77), vasopressor hormones (78-80), thrombin, transforming growth factor- $\beta$ (TGF- $\beta$ ) (81), pulsatile and shearstress (82), and hypoxia (83-85), whereas $\mathrm{NO}$ and prostacyclin reduce their expression (86). ET cause vasoconstriction (87), cell proliferation (88), and myocardial effects through activation of endothelin A (ETA) receptors $(89,90)$, but induce vasodilation through the release of nitric oxide and prostacyclin by endothelial ETB receptors (91).

ET-1, the main isoform in the human vasculature, is synthesized from its precursor (big endothelin-1) through an endothelin-converting enzyme. As shown in experimental models, ET-1 is produced within the myocardium when it is exposed to pathological stresses (92) such as hemodynamic overload caused by aortic constriction $(93,94)$, or after myocardial infarction (95), and seems to mediate the process of myocardial remodeling $(96,97)$. The rise in ET-1 levels is due to an increase in production (98), but the molecules stimulating this synthesis are still unknown.

ET-1 has been evaluated in humans and its plasma levels of ET-1 were high in patients with $\mathrm{CHF}$, correlated with the degree of pulmo- 
nary hypertension (99), and exercise impairment $(100,101)$. ET-1 and its precursor were related to both the magnitude of alterations in cardiac hemodynamics and functional class severity of CHF and to the patient's prognosis $(102,103)$.

The myocardium expresses both ETA and ETB receptors, and ETA receptors are increased, when myocardium is exposed to hemodynamic overload (99). Selective ETA and combined ETA-ETB antagonists have been studied in patients with CHF, showing hemodynamic improvement, i.e., reduced peripheral vascular and pulmonary resistence and increased cardiac output (104).

\section{Possible Causes of Immune Activation in Heart Failure}

The origin of the immune activation in patients with CHF is still unknown. Two hypotheses have been proposed on the basis of experimental and clinical data. One suggests that the bowel wall edema leads to bacterial translocation with subsequent endotoxin release and immune activation (105). High endotoxin levels have been found in $\mathrm{CHF}$ patients with peripheral edema (106). These endotoxin levels were paralleled by elevated TNF- $\alpha$ levels. After $23 \mathrm{~d}$ diuretic treatment, there was a fall in endotoxin levels but no change in TNF- $\alpha$. Only after $41 \mathrm{~d}$ of diuretic treatment was a small reduction of TNF- $\alpha$ seen. The authors concluded that high plasma levels of cytokines in CHF patients were due to the venous congestion, which can alter gut permeability for bacterial endotoxin, which can then be released into the circulation and bind to CD14 receptors, mainly expressed on monocytes and tissue macrophages, raising the synthesis of TNF.

The second suggestion is that the heart is the main source of cytokines, as shown by the fact that TNF- $\alpha$ is produced by the failing myocardium but not by a normal one $(107,108)$. Experimental proof of myocardial production of TNF- $\alpha$ has been proved by the fact that, in isolated cat heart, a high left ventricular distending pressure induced myocardial expression of TNF- $\alpha$ (109).

No single source of cytokine production (gut or heart) seems sufficient to fully explain the multiple organ involvement and the systemic inflammation of $\mathrm{CHF}$, which also have been related to systemic hypoxia (110). Hypoxia can be a potent stimulus for activation of the immune system and for cytokine production $(111,112)$. Figure 1 illustrates the main hypotheses of immune activation in CHF.

\section{Chf Therapies and the Immune System}

As the important role of the immune system in CHF becomes clear, many drugs used routinely in clinical practice have been seen to have anticytokine effects. 


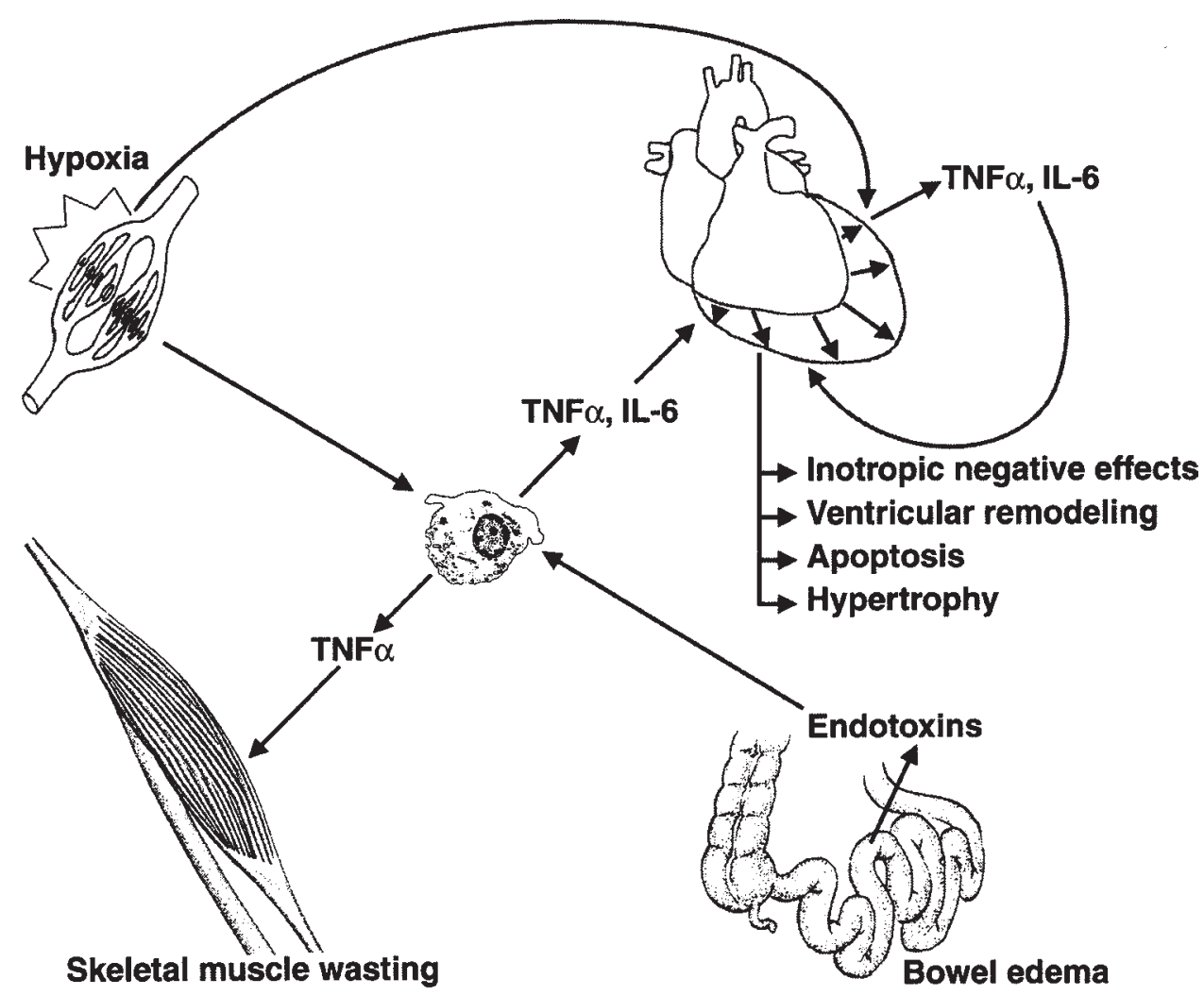

Fig. 1. The main potential pathways of immune activation in congestive heart failure. The edematous bowel wall facilitates entrance of the endotoxin into the circulation, stimulating the secretion of cytokines by leukocytes/macrophages and the failing myocardium. The cytokines then trigger immune activation, with deleterious effects on the myocardium. Cytokines can also be produced by the failing heart, setting a vicious circle between the heart and immune system activation. Hypoxia may contribute to the increase of cytokine production.

\section{Beta-Blockers}

From the 1970s to 1990s, there were some reports that proved betablocker were effective in some patients with $\mathrm{CHF}$, but the exact mechanism of action is still not known. One potential link is the effect of the sympathetic nervous system on immune function. Sympathetic overactivity might lead to immune alterations that contribute to progression of left ventricular dysfunction in the presence of heart failure (113). In patients with CHF of either ischemic or idiopathic etiology, metoprolol treatment improved cell-mediated immunity, especially the response to skin tests, and correlated with changes in ejection fraction. Additionally, there was increases in the natural killer (NK) cell population and in T-suppressor/cytotoxic cells; the authors concluded that the clinical improvement in patients taking beta-blockers may partly 
due to a blockade of sympathetic-induced immune abnormalities and that, if this is the case, further investigation into the role of immunologically mediated progression of left ventricular dysfunction is indicated (113).

A recent study in patients with idiopathic dilated cardiomyopathy noted significant reductions in serum levels of IL-10, TNF- $\alpha$, and sTNFR2 after beta-blockers were added to their therapies (digitalis, diuretics, and angiotensin-converting enzyme inhibitors) for $12 \mathrm{wk}$ (114). Another study suggested that metoprolol treatment in CHF is associated with a significant but temporary decrease in IL-2 receptors after 3 mo, possibly reflecting downmodulation of T-cell activation. However, enhanced immune activation also persisted in the metoprolol group, suggesting a potential for more specific immunomodulatory therapy (115).

\section{Calcium Antagonists}

The beneficial effect of amlodipine in CHF may be due to a reduction of cytokines such as IL-6, since in patients with CHF of NYHA III and IV amlodipine for $26 \mathrm{wk}$ lowered plasma IL-6 levels significantly (116). There was no decrease of TNF- $\alpha$. Adverse events or death were more common among patients with higher IL-6 levels.

\section{Angiotensin-Converting Enzyme (ACE) Inhibitors and Angiotensin II Receptor Antagonists}

ACE-inhibitors have favorable effects on mortality, morbidity (117), and ventricular remodeling (118) in CHF. They cause hemodynamic effects by reducing angiotensin II in plasma and tissue, raising the concentration of bradykinin or NO and inhibiting the sympathetic nervous system. Since certain ACE-inhibitors suppress IL-1 and TNF synthesis in vitro, probably at a post-transcriptional level (119), investigators have aimed to find out whether the ACE inhibitors also inhibit immune activation in $\mathrm{CHF}$.

In patients with severe $\mathrm{CHF}$, high-dose enalapril was associated with a significant decrease in IL-6 activity, but did not lower the levels of other immunological parameters (IL-1 $\beta$, IL-1Ra, TNF- $\alpha$, sTNF receptors), which were all significantly high at baseline, reflecting persistent immune activation in CHF (120). In other studies, ACE-inhibitors alone (121), or combined with milrinone (122), were associated with lower plasma TNF- $\alpha$ levels. ACE-inhibitors also suppressed lipopolysaccharide (LPS)-induced production of TNF- $\alpha$ in vitro and in vivo (123). High concentrations of captopril or valsartan had potent inhibitory effects on LPS-stimulated production of TNF and IL-1 in vitro, by increasing the anti-inflammatory cytokine IL-1Ra (captopril) and reducing IL-6 production (valsartan) (124). Long-term treatment with an angiotensin 
II type 1 receptor antagonist (candersartan cilexetil for $14 \mathrm{wk}$ ) significantly reduced plasma markers of immune activation (TNF- $\alpha$, IL-6) in patients with mild to moderate CHF (125).

\section{Phosphodiesterase Inhibitors}

Phosphodiesterase inhibitors such as amrinone, pimobendan, or vesnarinone, increase cAMP-mediated signaling in cardiac myocytes, producing beneficial effects in patients with heart failure (126). However, clinical trials have shown that chronic treatment with these drugs adversely affects survival (127). Phosphodiesterase inhibitors stop the production of proinflammatory cytokines in patients with CHF (128) and in experimental models (129). However, it is not clear whether this anticytokine effect improves cardiac function and clinical symptoms.

\section{New Approaches}

Specific anti-cytokine compounds have now been introduced for the management of CHF. Soluble TNF binding proteins (TNF-BP) were sufficient to prevent, and even reverse, the negative inotropic properties of TNF- $\alpha$ in isolated contracting cardiac myocytes. The TNF-BP that was most effective in blocking the negative inotropic effects of TNF- $\alpha$ was sTNFR:Fc (130). This is a dimer of two extracellular domains of TNFR2 (p75) fused in duplicate to the Fc portion of the human IgG1 molecule. A further study found that a single infusion of TNFR:Fc antagonized the negative inotropic effects of chronic TNF- $\alpha$ infusion in rats after $24 \mathrm{~h}$ (21). In transgenic mice overexpressing TNF, the analogous soluble TNF receptor prevented myocardial inflammation, blocking the expression of adhesion molecules and cytokines, and reduced left ventricular end-systolic diameter but not hypertrophy (131). Additional studies performed by the same group reported the ability of antiTNF therapy to modulate myocardial extracellular matrix remodeling and to partially reverse pathological cardiac changes in the transgenic murine model $(132,133)$.

In a pilot study, a single intravenous infusion of a soluble p75 TNF receptor fusion protein (Enbrel, etanercept), in patients with NYHA class III heart failure, reduced TNF bioactivity and produced a significant overall increase in quality-of-life scores, 6-min walk distance, and ejection fraction (134). The same authors have now published the result of 3 mo treatment with etanercept in patients with advanced heart failure, suggesting its safety and potential effectiveness in conjunction with conventional therapies, although they analyzed only a limited number of patients and for a short follow-up (135). Another group reported that the administration of etanercept improved systemic endothelial vasodilator capacity in patients with heart failure (136). On the other hand, 
preliminary results of an ongoing Phase II trial with infliximab in patients with moderate to severe heart failure demonstrated higher incidences of mortality and hospitalization for worsening heart failure, especially with the highest dosages (137).

It has also been reported that intravenous immunoglobulins can modulate the cytokine network in an antinflammatory direction; this is significantly correlated with improvement of the left ventricular ejection fraction (138).

\section{Acknowledgments}

F. Di Berardino is supported with a post-graduate fellowship of the I.R.C.C.S Maggiore Hospital, Ricerca Finalizzata 2000.

\section{References}

1. Cohn, J. N. (1996), N. Engl. J. Med. 335, 490-498.

2. Cohn, J. N. (2001), Hypertension 37, 346-349.

3. Francis, G. S., Goldsmith, S. R., Levine, T. B., Olivari, M. T., and Cohn, J. N. (1984), Ann. Intern. Med. 101, 370-377.

4. Pfeffer, J. M. and Pfeffer, M. A. (1988), Am. J. Med. 84, 37-44.

5. Levine, B., Kalman, J., Mayer, L., Fillit, H. M., and Packer, M. (1990) N. Engl. J. Med. 323, 236-241.

6. Kapadia, S., Dibbs, Z., Kurrelmeyer, K., Karla, D., Seta, Y., Wang, F., et al. (1998), Cardiology Clinics 16, 645-656.

7. Damas, J. K., Gullestad, L., Ueland, T., Solum, N. O., Simonsen, S., Froland, S. S., and Aukrust, P. (2000), Cardiovasc. Res. 45, 428-436.

8. Sharma, R., Coats, A. J., and Anker, S. D. (2000), Int. J. Cardiol. 72, 175-186.

9. Packer, M. (1995), Circulation 92, 1379-1382.

10. McMurray, J., Abdullah, I., Dargie, H. J., and Shapiro, D. (1991), Br. Heart J. 66, 356-358.

11. Dutka, D. P., Elborn, J. S., Delamere, F., Shale, D. J., and Morris, G. K. (1993), Br. Heart J. 70, 141-143.

12. Katz, S. D., Rao, R., Berman, J. W., Schwarz, M., Demopoulos, L., Bijou, R., and LeJemtel, T. H. (1994), Circulation 90, 12-16.

13. Wiedermann, C. J., Bermpold, H., Manfred, H., Knapp, E., and Braunstein, H. (1993), J. Am. Coll. Cardiol. 22, 1897-1901.

14. Torre-Amione, G., Kapadia, S., Benedict, C., Oral, H., Young, J. B., and Mann, D. L. (1996), J. Am. Coll. Cardiol. 27, 1201-1206.

15. Kubota, T., Miyagishima, M., Alvarez, R. J., Kormos, R., Rosenblum, W. D., Demetris, A. J., et al. (2000), J. Heart Lung Transpl. 19, 819-824.

16. Torre-Amione, G., Stetson, S. J., Youker, K. A., Durand, J. B., Radovancevic, B., Delgado, R. M., et al. (1999), Circulation 100, 1189-1193.

17. Finkel, M. S., Oddis, C. V., Jacob, T. D., Watkins, S. C., Hattler, B. G., and Simmons, R. L. (1992), Science 257, 387-389.

18. Balligand. J.-L., Kelly, R. A., Marsden, P. A., Smith, T. W., and Michel, T. (1993), Proc. Natl. Acad. Sci. USA 90, 347-351.

19. Hocking, D. C., Phillips, P. G., Ferro, T. J., and Johnson, A. (1990), Circ. Res. 67, 68-77.

20. Hegewisch, S., Weh, H. J., and Hossfield, D. K. (1990), Lancet 335, 294-295.

21. Bozkurt, B., Kribbs, S., Clubb, F. J., Jr., Michael, L. H., Didenko, V. V., Hornsby, P. J., et al. (1998), Circulation 97, 1382-1391. 
22. Tracey, K. J., Morgello, S., Koplin, B., Fahey, T. J., 3rd, Fox, J., Aledo, A., et al. (1990), J. Clin. Invest. 86, 2014-2024.

23. Krown, K. A., Page, M. T., Nguyen, C., Zechner, D., Gutierrez, V., Comstock, K. L., et al. (1996), J. Clin. Invest. 98, 2854-2865.

24. Anker, S. D., Chua, T. P., Ponikowski, P., Harrington, D., Swan, J. W., Kox, W. J., et al. (1997), Circulation 96, 526-534.

25. Kapadia, S. R. (1998), Cardiology Rev. 7, 196-206.

26. Ferrari, R., Bachetti, T., Confortini, R., Opasich, C., Febo, O., Corti, A., et al. (1995), Circulation 92, 1479-1486.

27. Deswal, A., Petersen, N. J., Feldman, A. M., Young, J. B., White, B. G., and Mann, D. L. (2001), Circulation 103, 2055-2059.

28. Rauchhaus, M., Doehner, W., Francis, D. P., Davos, C., Kemp, M., Liebenthal, C., et al. (2000), Circulation 102, 3060-3067.

29. Dinarello, C. A. (1996), Blood 87, 2095-2147.

30. Libby, P., Warner, S. J., and Friedman, G. B. (1988), J. Clin. Invest. 81, 487-498.

31. Palmer, J. N., Hartogensis, W. E., Patten, M., Fortuin, F. D., and Long, C. S. (1995), I. Clin. Invest. 95, 2555-2564.

32. Shioi, T., Matsumori, A., Kihara, Y., Inoko, M., Ono, K., Iwanaga, Y., et al. (1997), Circ. Res. 81, 664-671.

33. Francis, S. E., Golden, H., Holt, C. M., and Duff, G. W. (1998), J. Mol. Cell. Cardiol. 30, 215-223.

34. Gulick, T., Chung, M. K., Pieper, S. J., Lange, L. G., and Schreiner, G. F. (1989), Proc. Natl. Acad. Sci. USA 86, 6753-6857.

35. Munger, M. A., Johnson, B., Amber, I. J., Callahan, K. S., and Gilbert, E. M. (1996), Am. J. Cardiol. 77, 723-727.

36. Aukrust, P., Ueland, T., Lien, E., Bendtzen, K., Muller, F., Andreassen, A. K., et al. (1999), Am. J. Cardiol. 83, 376-382.

37. Roig, E., Orus, J., Pare, C., Azqueta, M., Filella, X., Perez-Villa, F., et al. (1998), Am. J. Cardiol. 82, 688-690, A8.

38. Carlstedt, F., Lind, L., and Lindahl, B. (1997), J. Intern. Med. 242, 361-365.

39. Kunisada, K., Hirota, H., Fujio, Y., Matsui, H., Tani, Y., Yamauchi-Takihara, K., and Kishimoto, T. (1996), Circulation 94, 2626-2632.

40. Raymond, R. J., Dehmer, G. J., Theoharides, T. C., and Deliargyris, E. N. (2001), Am. Heart J. 141, 435-438.

41. Tsutamoto, T., Hisanaga, T., Wada, A., Maeda, K., Ohnishi, M., Fukai, D., et al. (1998), J. Am. Coll. Cardiol. 31, 391-398.

42. Orus, J., Roig, E., Perez-Villa, F., Pare, C., Azqueta, M., Filella, X., et al. (2000), J. Heart Lung Transpl. 19, 419-425.

43. Citterio, G., Fragasso, G., Rossetti, E., Di Lucca, G., Bucci, E., Foppoli, M., et al. (1996), J. Immunother. 19, 134-141.

44. Testa, M., Yeh, M., Lee, P., Fanelli, R., Loperfido, F., Berman, J. W., and LeJemtel, T. H. (1996), J. Am. Coll. Cardiol. 28, 964-971.

45. Fuchs, D., Samsonov, M., Tilz, G. P., Reibnegger, G., Belenkov, J. N., Nassonov, E. L., and Wachter, H. (1993), Eur. J. Clin. Chem. Clin. Biochem. 31, 111-114.

46. Samsonov, M., Lopatin, J., Tilz, G. P., Artner-Dworzak, E., Nassonov, E., Mareev, V., et al. (1998), J. Intern. Med. 243, 93-98.

47. Fiorina, P., Astorri, E., Albertini, R., Secchi, A., Mello, A., Lanfredini, M., et al. (2000), J. Clin. Immunol. 20, 101-106.

48. Aukrust, P., Ueland, T., Muller, F., Andreassen, A. K., Nordoy, I., Aas, H., et al. (1998), Circulation 97, 1136-1143.

49. Cook, D. N., Becj, M. A., Coffman, T. M., Kirby, S. L., Sheridan, J. F., Pragnell, I. B., and Smithies, O. (1994), Science 269, 1583-1585.

50. Yeh, E. T. H. (1997), Circulation 95, 782-786.

51. Buttke, T. M. and Sandstrom, P. A. (1994), Immunol. Today 15, 7-10. 
52. Latif, N., Baker, C. S., Dunn, M. J., Rose, M. L., Brady, P., and Yacoub, M. H. (1993), J. Am. Coll. Cardiol. 22, 1378-1384.

53. Bilinska, Z., Caforio, A., Kusmierezyk-Droszez, B., Michalak, E., Grzybowski, J., Goldman, J., et al. (1996), Clin. Cardiol. 19, 794-798.

54. Mestroni, L., Rocco, C., Gregori, D., Sinagra, G., Di Lenarda, A., Miocic, S., et al. (1999), J. Am. Coll. Cardiol. 34, 181-190.

55. Limas, C. J., Goldenberg, I. F., and Limas, C. (1989), Circ. Res. 64, 171-174.

56. Jahns, R., Boivin, V., Siegmund, C., Inselmann, G., Lohse, M. J., and Boege, F. (1999), Circulation 99, 649-654.

57. Jahns, R., Boivin, V., Krapf, T., Wallukat, G., Boege, F., and Lohse, M. J. (2000), J. Am. Coll. Cardiol. 36, 1280-1287.

58. Muller, J., Wallukat, G., Dandel, M., Bieda, H., Brandes, K., Spiegelsberger, S., et al. (2000), Circulation 101, 385-391.

59. Felix, S. B., Staudt, A., Dorffel, W. V., Stangl, V., Merkel, K., Pohl, M., et al. (2000), J. Am. Coll. Cardiol. 35, 1590-1598.

60. Dorffel, W. V., Wallukat, G., Baumann, G., and Felix, S. B. (2000), Therap. Apheresis 4, 235-238.

61. Bevilacqua, M. P. (1993), Annu. Rev. Immunol. 11, 767-804.

62. Patarroyo, M. and Makgoba, M. W. (1989), Lancet 2, 1139-1142.

63. Cronstein, B. N. and Weissmann, G. (1993), Arthritis Rheum. 36, 147-157.

64. Abbas, A. K., Lichtman, A. H., and Pober, J. S., eds. (2000), Cellular and Molecular Immunology. W.B. Saunders Co., Philadelphia, p. 279.

65. Bevilacqua, M. P., Pober, M. S., Wheeler, M. E., Cotran, R. S., and Gibrone, M. A., Jr. (1989), J. Clin. Invest. 76, 2003-2011.

66. Pober, J. S. and Cotran, R. S. (1990), Transplantation 50, 537-544.

67. Devaux, B., Scholz, D., Hirche, A., Klovekorn, W. P., and Schaper, J. (1997), Eur. Heart J. 18, 470-479.

68. Tsutamoto, T., Hisanaga, T., Fukai, D., Wada, A., Maeda, Y., and Kinoshita, M. (1995), Am. J. Cardiol. 76, 803-808.

69. Andreassen, A. K., Nordoy, I., Simonsen, S., Ueland, T., Muller, F., Froland, S. S., et al. (1998), Am. J. Cardiol. 81, 604-608.

70. Del Balzo, U., Sakuma, I., and Levi, R. (1990), J. Pharmacol. Exp. Ther. 253, 171-179.

71. Vakeva, A. P., Agah, A., Rollins, S. A., Matis, L. A., Li, L., and Stahl, G. L. (1998), Circulation 97, 2259-2267.

72. Hopken, U. E., Lu, B., Gerard, N. P., and Gerard, C. (1997), J. Exp. Med. 186, 749-756.

73. Clark, D. J., Cleman, M. W., Pfau, S. E., Rollins, S. A., Ramahi, T. M., Mayer, C., et al. (2001), Am. Heart. J. 141, 684-690.

74. Ohta, K., Hirata, Y., Imai, T., Kanno, K., Emori, T., Shichiri, M., and Marumo, F. (1990), Biochem. Bioph. Res. Co. 169, 578-584.

75. Kanse, S. M., Takahashi, K., Lam, H. C., Rees, A., Warren, J. B., Porta, M., et al. (1991), Life Sci. 48, 1379-1384.

76. Miyamori, I., Takeda, Y., Yoneda, T., Iki, K., and Takeda, R. (1991), Life Sci. 49, 1295-1300.

77. Woods, M., Bishop-Bailey, D., Pepper, J. R., Evans, T. W., Mitchell, J. A., and Warner, T. D. (1998), J. Cardiovasc. Pharm. 31, S348-S350.

78. Kohno, M., Murakawa, K., Yokokawa, K., Yasunari, K., Horio, T., Kurihara, N., and Takeda, T. (1989), J. Hypertens. 7, S130-S131.

79. Dohi, Y., Hahn, A. W., Boulanger, C. M., Buhler, F. R., and Luscher, T. F. (1992), Hypertension 19, 131-137.

80. Barton, M., Shaw, S., D’Uscio, L. V., Moreau, P., and Luscher, T. F. (1997), Biochem. Bioph. Res. Co. 238, 861-865. 
81. Boulanger, C. M., Tanner, F. C., Bea, M. L., Hahn, A. W., Werner, A., and Luscher, T. F. (1992), Circ. Res. 70, 1191-1197.

82. Macarthur, H., Warner, T. D., Wood, E. G., Corder, R., and Vane, J. R. (1994), Biochem. Bioph. Res. Co. 200, 395-400.

83. Kourembanas, S., Marsden, P. A., McQuillan, L. P., and Faller, D. V. (1991), J. Clin. Invest. 88, 1054-1057.

84. Shirakami, G., Nakao, K., Saito, Y., Magaribuchi, T., Jougasaki, M., Mukoyama, M., et al. (1991), Life Sci. 48, 969-976.

85. Hieda, H. S. and Gomez-Sanchez, C. E. (1990), Life Sci. 47, 247-251.

86. Boulanger, C. and Luscher, T. F. (1990), J. Clin. Invest. 85, 587-590.

87. Sumner, M. J., Cannon, T. R., Mundin, J. W., White, D. G., and Watts, I. S. (1992), Br. J. Pharmacol. 107, 858-860.

88. Hirata, Y., Takagi, Y., Fukuda, Y., and Marumo, F. (1989), Atherosclerosis 78, 225-228.

89. McMurray, J. J., Ray, S. G., Abdullah, I., Dargie, H. J., and Morton, J. J. (1992), Circulation 85, 1374-1379.

90. Rodeheffer, R. J., Lerman, A., Heublein, D. M., Burnett, J. J. (1992), Mayo Clin. Proc. 67, 719-724.

91. Verhaar, M. C., Strachan, F. E., Newby, D. E., Cruden, N. L., Koomans, H. A., Rabelink, T. J., and Webb, D. J. (1998), Circulation 97, 752-756.

92. Sam, F. and Colucci, W. S. (1998), Cardiologia 43, 889-892.

93. Ito, H., Hiroe, M., Hirata, Y., Fujisaka, H., Adaki, S., Akimoto, H., Ohta, Y., and Marumo, F. (1994), Circulation 89, 2198-2203.

94. Arai, M., Yoguchi, A., Iso, T., Takahashi, T., Imai, S., Murata, K., and Suzuki, T. (1994), Am. J. Physiol. 268, 2084-2091.

95. Tonnessen, T., Christensen, G., Oie, E., Holt, E., Kjeshus, H., Smiseth, O. A., et al. (1997), Cardiovasc. Res. 33, 601-610.

96. Weber, K. T., Sun, Y., and Guarda, E. (1993), Hypertension 23, 869-877.

97. Tsutamoto, T., Wada, A., Maeda, K., Mabuchi, N., Hayashi, M., Tsutsui, T., et al. (2000), Am. J. Cardiol. 86, 524-528.

98. Margulies, K. B., Hildebrand, F. L., Lerman, A., Perrella, M. A., and Burnett, J. C., Jr. (1994), Circulation 82, 2226-2230.

99. Cody, R. J., Haas, G. J., Binkley, P. F., Capers, Q., and Kelley, R. (1992), Circulation 85, 504-509.

100. Mangieri, E., Tanzilli, G., Barilla, F., Ciavolella, M., Serafini, G., Nardi, M., et al. (1997), Am. J. Cardiol. 79, 1261-1263.

101. Krum, H., Goldsmith, R., Wilshire-Clement, M., Miller, M., and Packer, M. (1995), Am. J. Cardiol. 75, 1282-1283.

102. Wei, C. M., Lerman, A., Rodeheffer, R. J., McGregor C. G., Brandt, R. R., Wriht, S., et al. (1994), Circulation 89, 1580-1586.

103. Pacher, R., Stanek, B., Hulsmann, M., Koller-Strametz, J., Berger, R., Schuller, M., et al. (1996), J. Am. Coll. Cardiol. 27, 633-641.

104. Spieker, L. E., Noll, G., Ruschitzka, F. T., and Luscher, T. F. (2001), J. Am. Coll. Cardiol. 37, 493-505.

105. Anker, S. D., Egerer, K., Volk, H.-D., Kox, W. J., Poole-Wilson, P. A., and Coats, A. J. S. (1997), Am. J. Cardiol. 79, 1426-1430.

106. Niebauer, J., Volk, H.-D., Kemp, M., Dominiguez, M., Schumann, R. R., Rauchhaus, M., et al. (1999), Lancet 353, 1838-1842.

107. Torre-Amione, G., Kapadia, S., Lee, J., Durand, J. B., Bies, R. D., Young, J. B., and Mann, D. L. (1996), Circulation 93, 704-711.

108. Habib, F. M., Springall, D. R., Davies, G. J., Oakley, C. M., Yacoub, M. H., and Polak, J. M. (1996), Lancet 347, 1151-1155. 
109. Kapadia, S. R., Oral, H., Lee, J., Nakano, M., Taffet, G. E., and Mann, D. L. (1997), Circ. Res. 81, 47-56.

110. Hasper, D., Hummel, M., Kleber, F. X., Reindl, I., Volk, H.-D. (1998), Eur. Heart J. 19, 761-765.

111. Shreeniwas, R., Koga, S., Karakurum, M., Pinsky, D., Kaiser, E., Brett, J., et al. (1992), J. Clin. Invest. 90, 2333-2339.

112. Scannell, G., Waxman, K., Kaml, G. J., Ioli, G., Gatanaga, T., Yamamoto, R., and Granger, G. A. (1993), J. Surg. Res. 54, 281-285.

113. Maisel, A. S. (1994), Circulation 90, 1774-1780.

114. Ohtsuka, T., Hamada, M., Hiasa, G., Sasaki, O., Suzuki, M., Hara, Y., et al. (2001), J. Am. Coll. Cardiol. 37, 412-417.

115. Gullestad, L., Ueland. T., Brunsvig A., Kjekshus, J., Simonsen, S., Froland, S. S., and Aukrust, P. (2001), Am. Heart J. 141, 418-421.

116. Mohler, E. R., 3rd, Sorensen, L. C., Ghali, J. K., Schocken, D. D., Willis, P. W., Bowers, J. A., et al. (1997), J. Am. Coll. Cardiol. 30, 35-41.

117. The CONSENSUS Trial Study Group. (1987), N. Engl. J. Med. 316, 1429-1435.

118. Dunn, F. G., Oigman, W., Ventura, H. O., Messerli, F. H., Kobrin, I., and Frohlich, E. D. (1984), Am. J. Cardiol. 53, 105-108.

119. Schindler, R., Dinarello, C. A., and Koch, K. M. (1995), Cytokine 7, 526-533.

120. Gullestad, L., Aukrust, P., Ueland, T., Espevik, T., Yee, G., Vagelos, R., et al. (1999), J. Am. Coll. Cardiol. 34, 2061-2067.

121. Stenvinkel, P., Andersson, P., Wang, T., Lindholm, B., Bergstrom, J., Palmblad, J., et al. (1999), J. Intern. Med. 246, 503-507.

122. Liu, L. and Zhao, S. P. (1999), Int. J. Cardiol. 69, 77-82.

123. Fukuzawa, M., Satoh, J., Sagara, M., Muto, G., Muto, Y., Nishimura, S., et al. (1997), Immunopharmacology 36, 49-55.

124. Peeters, A. C., Netea, M. G., Kullberg, B. J., Thien, T., and van der Meer, J. W. (1998), Immunology 94, 376-379.

125. Tsutamoto, T., Wada, A., Maeda, K., Mabuchi, N., Hayashi, M., Tsutsui, T., et al. (2000), J. Am. Coll. Cardiol. 35, 714-721.

126. Bristow, M. R., Port, J. D., and Kelly, R. A. (2001), in Heart Disease: A Textbook of Cardiovascular Medicine, Braunwald, E., Zipes, D. P., and Libby, P., eds., W.B. Saunders Co., Philadelphia, pp. 562-599.

127. Cohn, J. N., Goldstein, S. O., Greenberg, B. H., Lorell, B. H., Bourge, R. C., Jaski, B. E., et al. (1998), N. Engl. J. Med. 339, 1801-1816.

128. Matsumori, A., Shioi, T., Yamada, T., Matsui, S., and Sasayama, S. (1994), Circulation 89, 955-958.

129. Iwasaki, A., Matsumori, A., Yamada, T., Shioi, T., Wang, W., Ono, K., et al. (1999), J. Am. Coll. Cardiol. 33, 1400-1407.

130. Kapadia, S., Torre-Amione, G., Yokoyama, T., and Mann, D. L. (1995), Am. J. Physiol. 268, H517-H525.

131. Kubota, T., Bounoutas, G. S., Miyagishima, M., Kadokami, T., Sanders, V. J., Bruton, C., et al. (2000), Circulation 101, 2518-2525.

132. Li, Y. Y., Feng, Y. Q., Kadokami, T., McTiernan, C. F., Draviam, R., Watkins, S. C., and Feldman, A. M. (2000), PNAS 97, 12746-12751.

133. Kadokami, T., Frye, C., Lemster, B., Wagner, C. L., Feldman, A. M., and McTiernan, C. F. (2001), Circulation 104, 1094-1097.

134. Deswal, A., Bozkurt, B., Seta, Y., Parilti-Eiswirth, S., Hayes, F. A., Blosch, C., and Mann, D. L. (1999), Circulation 99, 3224-3226.

135. Bozkurt, B., Torre-Amione, G., Warren, M. S., Whitmore, J., Soran, O. Z., Feldman, A. M., et al. Circulation 103, 1044-1047. 
136. Fichtlscherer, S., Rossig, L., Breuer, S., Vasa, M., Dimmeler, S., and Zeiher, A. M. (2001), Circulation 104, 3023-3025.

137. 2001, FDA Safety Information Summaries; http://www.fda.gov/medwatch/ safety/2001/safety01.htm\#biologics

138. Gullestad, L., Aass, H., Fjeld, J. G., Wikeby, L., Andreassen, A., Ihlen, H., et al. (2001), Circulation 103, 220-225. 